\title{
Production of Natural Insecticide on Management of Plutella xylostella (Linnaeus, 1758) (Lepidoptera: Plutellidae) in Family Farming
}

\author{
Cristiane G. L. Ruiz ${ }^{1}$, Marilza S. Costa ${ }^{2}$, Santino Seabra Jr. ${ }^{1}$ \& Mônica J. B. Pereira ${ }^{1,2}$ \\ ${ }^{1}$ Post Graduate Program in Agriculture and Agricultural Production Systems, University of Mato Grosso State, \\ Tangará da Serra, MT, Brazil \\ ${ }^{2}$ Laboratory of Entomology, Center for Research, Studies and Agro-Environmental Development, University of \\ Mato Grosso State, Tangará da Serra, MT, Brazil \\ Correspondence: Marilza S. Costa, Laboratory of Entomology, Center for Research, Studies and \\ Agro-Environmental Development, University of Mato Grosso State, Tangará da Serra, MT, Brazil. Tel: \\ 55-65-3311-4920. E-mail: marilzacosta@gmail.com
}

Received: April 21, 2021

Accepted: May 30, 2021

Online Published: June 15, 2021

doi:10.5539/jas.v13n7p47

URL: https://doi.org/10.5539/jas.v13n7p47

\begin{abstract}
Collard greens are commonly grown in family farming systems; however, damage caused by the diamondback moth Plutella xylostella (Lepidoptera: Plutellidae) reduces yields, leading to successive applications of insecticides and consequently, environmental and toxicological problems. Therefore, it is essential to search for alternatives that reduce the use of pesticides and are economically viable and accessible to small farmers. This study was aimed at evaluating the insecticidal activity of aqueous extracts of neem and tobacco on P. xylostella. First instar caterpillars were offered collard leaf discs treated with different concentrations ( 30 caterpillars per treatment) and after the third day, mortality was evaluated. To evaluate ovicidal properties, collard leaves with 30 eggs were immersed in extracts and after $48 \mathrm{~h}$, viability was measured. Oviposition deterrent activity was assessed with 23 couples of $P$. xylostella released in cages (repetitions) containing treated collard plants and after $48 \mathrm{~h}$, the number of eggs per plant was recorded. Neem and tobacco extracts exhibited larvicidal, ovicidal, and oviposition deterrent properties against $P$. xylostella, indicating that the use of these extracts may be promising alternatives in family farming systems.
\end{abstract}

Keywords: Plutella xylostella, aqueous extract, Azadirachta indica, Nicotina tabacum

\section{Introduction}

In Brazil, the consumption of collards (Brassica oleracea var. acephala (L.)) has gradually increased because of its high content of vitamins and minerals, important for human nutrition (Faria, Arruda, Araújo, \& Penteado, 2017). Recently, $98 \%$ of the production volume of this leafy green is concentrated in small farms (Mitidiero Junior, Barbosa, \& Sá, 2017), mainly due to low production costs and ease of propagation, which facilitate the implementation of operations and generate jobs and income (Trani et al., 2015). Although the southeastern region of Brazil is the largest producer of collard greens (Trani et al., 2015), in the Central-Western region, this crop is socioeconomically important, producing annually 5,347 tons, of these, the state of Mato Grosso contributed 874 tons $(0.93 \%)$ (Melo et al., 2017).

The annual production of collards, however, is adversely affected by phytosanitary issues, mainly pest insects that are difficult to control and may cause severe damage to plants. Among these insects, the diamondback moth Plutella xylostella (Linnaeus, 1758) (Lepidoptera: Plutellidae) (Kianpour, Fathipour, Karimzadeh, \& Hosseininaveh, 2014) is considered a key pest due to the direct damage it causes to the commercial product. It feeds on the leaf epidermis, reducing the photosynthetic area of the plant and consequently yields, in addition to depreciating the product for commercialization (A. S. De Bortoli, Polanczyk, Vacari, C. P. De Bortoli, \& Duarte, 2013).

In small properties, farmers usually control this pest with chemical insecticides (Bon et al., 2014). Despite being effective in managing pests, this method can lead to the selection of resistant populations (Jiang, Wu, Yang, Zhu, 
\& Gao, 2015), reduction of beneficial natural enemies, and especially the contamination of the final commercial product (leaves) with toxic residues (PARA, 2013), a risk to consumer health.

Given this scenario, there is an imminent need for alternatives to pesticide use that can effectively control $P$. xylostella in collard-producing farms at low production costs. Therefore, the use of aqueous plant extracts may be considered a viable tool for pest management.

In small properties, the use of plants to control P. xylostella may be effective and safer than synthetic chemicals due to its weaker residual effect on non-target organisms (Raguraman \& Kannan, 2014) and that can be combined with other control practices (Al-Anany, El-Sheshtawy, Ghanem, \& El-Arnaouty, 2017). In family farming systems, botanical insecticides are an excellent alternative because they are less expensive and readily available from commonly grown plants (Amoabeng, Gurr, Gitau, \& Stevenson, 2014; Salim \& Abed, 2015).

The efficacy of neem extract (Azadirachta indica A. Juss) has been demonstrated by reducing feeding, interfering in the molting process and reproductive potential of adults, in addition to increasing mortality and decreasing viability of larvae and eggs, respectively, of several species of lepidopterans (Gahukar, 2014). Another plant with promising insecticidal properties is tobacco (Nicotiana tabacum L.), with aqueous extract capable of causing high mortality during the larval stage and deterring oviposition in adults of $P$. xylostella (Cerda, Ledezma-Carrizalez, Andino, Chiurato, \& Carpio, 2017).

It should be pointed out that vegetables consumed fresh, such as collards, with pesticide residues above acceptable levels lead to the commercialization of contaminated products, consequently decreasing food security. Therefore, the use of plant extracts in pest control can ensure the supply of safe and sustainable food to the consumer market (Lengai, Muthomi, \& Mbega, 2020).

Thus, given the relevance of the diamondback moth and the need to consume healthier foods, this study was aimed at evaluating the insecticidal potential of aqueous extracts of neem (A. indica) and tobacco ( $N$. tabacum) as alternatives for the control of this pest in family farming.

\section{Method}

\subsection{Study Site}

The study was conducted under controlled laboratory conditions $\left(25 \pm 3{ }^{\circ} \mathrm{C}, 60 \pm 10 \%\right.$ relative humidity, $12-\mathrm{h}$ photophase) and in a greenhouse of the Laboratory of Entomology, Center for Research, Agri-Environmental Studies and Development (CPEDA/UNEMAT), Mato Grosso State University, campus of Tangara da Serra/MT, Brazil.

\subsection{Collard Greens Growing}

For the bioassays, Hi-Crop collard greens (early hybrid-Takii ${ }^{\circledR}$ ) seeds were sown in expanded polystyrene 128-cell trays with commercial substrate (Plantmax ${ }^{\circledR}$ HP) and maintained in a greenhouse. After 30 days, seedlings with four true leaves were transplanted into $10 \mathrm{~L}$ pots and received the recommended fertilization for the crop and overhead irrigation three times a day.

\subsection{Plutella xylostella Rearing}

Leaves infested by P. xylostella were collected in collard fields in Tangara da Serra, Mato Grosso, Brazil. Newly hatched caterpillars were confined in $8 \mathrm{~L}$ plastic containers, covered with voile on one side and on the top. Inside the container, collard leaves with stalks wrapped in moist cotton served as a feeding substrate and were replaced every two days until caterpillars reached the pupal phase (Torres et al., 2006).

Pupae were kept in Petri dishes, inside wooden screened cages $(50 \times 50 \times 50 \mathrm{~cm})$, and after emergence, adults were fed a honey solution (10\%) soaked in cotton. Collard leaves were offered as an oviposition substrate and eggs were removed every two days and placed in plastic pots until the caterpillars hatched.

\subsection{Plant Extract Preparation}

For the preparation of neem extract, unripe seeds harvested in Tangara da Serra/MT (14 $37^{\prime} 10^{\prime \prime}$ S, 57 $7^{\circ} 29^{\prime} 09^{\prime \prime}$ W) were used. A voucher specimen was deposited at the Tangara Herbarium (TANG) and assigned the number 3031. A stock solution was prepared with freshly harvested seeds crushed in a blender $(10 \mathrm{~g})$ and distilled water was added to the mixture until reaching a volume of $100 \mathrm{~mL}$ in a concentration (mass/volume) of $10 \%$. The neem suspension was filtered using voile fabric following preparation and used in bioassays.

For the aqueous tobacco extract, the commercial product Trevo ${ }^{\circledR}$ was used. A suspension was prepared with 10 $\mathrm{g}$ of the product in a final volume $100 \mathrm{~mL}$ of distilled water at a concentration of $10 \%$ (mass/volume) and kept in 
a closed container for $24 \mathrm{~h}$ for the extraction of water-soluble compounds. After this period, the mixture was filtered with voile fabric (Boiça Júnior et al., 2005).

For both extracts, dilutions at the concentrations (mass/volume) of $0.0,0.5,1.0,2.0,4.0,6.0,8.0$, and 10.0\% were prepared. The toxicity bioassays with caterpillars and eggs were carried out using a completely randomized design (CRD) and the concentrations with the most promising larvicidal activity of each extract were used in the bioassays on eggs and oviposition repellency. Before applying the extracts, the solution was stirred to homogenize the mixture.

\subsection{Effects of Aqueous Extracts on P. xylostella Caterpillars}

To evaluate the effect of ingestion of aqueous extracts on caterpillars, collard leaf discs $(8 \mathrm{~cm}$ in diameter) were immersed for four seconds in solutions of different concentrations of neem and tobacco extracts. After brief evaporation at room temperature, discs were individually transferred to Petri dishes lined with filter paper $(8 \mathrm{~cm})$ moistened with distilled water. One first instar caterpillar (between 0 and $12 \mathrm{~h}$ of age) was then placed on each disc with the aid of a brush. Each petri dish was considered a repetition, totaling eight treatments per extract, with 30 repetitions each.

The first evaluation was carried out three days after the start of the bioassay because of the leaf-mining habit of $P$. xylostella caterpillars. Discs were then replaced with untreated ones daily and the number of live caterpillars was assessed in each treatment.

\subsection{Effects of Aqueous Extracts on P. xylostella Eggs}

Collard leaves with 24-hour-old eggs were cut so that they contained 30 eggs each, totaling 30 repetitions per treatment (900 eggs). They were then immersed for four seconds in the extracts and allowed to air dry at room temperature. Leaf cuttings with treated eggs were transferred to Petri dishes and non-viable eggs were counted after 48,72, and $96 \mathrm{~h}$ in each treatment with the aid of a stereomicroscope.

\subsection{Effects of Aqueous Extracts on P. xylostella Oviposition}

A bioassay was carried out to evaluate the oviposition deterrent action of the extracts and the insecticide with a chance of choice in a greenhouse, with 50-day-old collard plants with three leaves arranged in $10 \mathrm{~L}$ pots. The experimental design used was completely randomized with four treatments: aqueous neem and tobacco extracts, and as controls, distilled water and the insecticide methomyl $(1 \mathrm{~mL} / \mathrm{L})$, with four replicates (cages) each.

Plants were sprayed with approximately $250 \mathrm{~mL}$ of each extract or insecticide (per plant), with the aid of a $\mathrm{CO}_{2}$ pump at a constant flow rate of $200 \mathrm{~L} \mathrm{~h}^{-1}$. After the treatment, pots were grouped in pairs inside cages $(50 \times 75$ $\mathrm{cm}$ ) covered with voile containing a treated plant (plant extract or methomyl) and a plant sprayed with distilled water. After $12 \mathrm{~h}$ of application, 23 pairs of P. xylostella (newly emerged) were added to each cage and after $48 \mathrm{~h}$, the number of eggs in each plant was counted.

The repellent effect of the treatments was evaluated using the formula adapted from Obeng-Ofori (1995):

$$
P R=(N C-N T) /(N C+N T) \times 100
$$

Where, PR is the mean percentage of repellency; NC, the number of eggs in the treatment with distilled water; and NT, the number of eggs in each treatment with extract or methomyl. Based on the formula, the following classification was used: Repellent: PR $>0$; Non-repellent: PR $<0$ (Torres et al., 2006).

\subsection{Data Analysis}

The toxicity data of the extracts on caterpillars and eggs were analyzed with the Shapiro-Wilk and Barlett tests to check the assumptions of normality and homoscedasticity, respectively. If the necessary assumptions were satisfied, a one-way ANOVA was performed and the means were compared using the Scott-Knott test $(\mathrm{P}<0.05)$ with the software R version 3.2.3 (R Core Team, 2014).

\section{Results and Discussion}

\subsection{Effect of Aqueous Extracts on P. xylostella Caterpillars}

The aqueous extracts of neem and tobacco increased the mortality rate of first instar caterpillars of $P$. xylostella in a dose-dependent manner up to $2.0 \%$ and $4.0 \%$, respectively. Above these concentrations, mortality rates were close to $100 \%$, demonstrating the susceptibility of caterpillars during this instar to extracts (Table 1). 
Table 1. Average and percentage of mortality of first instar caterpillars of Plutella xylostella fed with collard discs (Brassica oleracea var acephala) treated with aqueous extracts of Azadirachta indica (Neem) and Nicotiana tabacum (Tobacco) $\left(25 \pm 3{ }^{\circ} \mathrm{C}, 60 \pm 10 \%\right.$, RH, Photophase $12 \mathrm{~h}$ )

\begin{tabular}{|c|c|c|c|c|}
\hline \multirow{2}{*}{ Treatment (\%) } & \multicolumn{2}{|c|}{ Neem } & \multicolumn{2}{|c|}{ Tobacco } \\
\hline & $(\mathrm{X} \pm \mathrm{SD})^{\mathrm{b}}$ & $\%$ & $(\mathrm{X} \pm \mathrm{SD})^{\mathrm{b}}$ & $\%$ \\
\hline 0.0 & $0.10 \pm 0.30 \mathrm{c}$ & 10.0 & $0.40 \pm 0.49 \mathrm{c}$ & 40.0 \\
\hline 0.5 & $0.73 \pm 0.47 \mathrm{~b}$ & 73.0 & $0.76 \pm 0.43 b$ & 76.6 \\
\hline 1.0 & $0.63 \pm 0.49 \mathrm{~b}$ & 63.3 & $0.90 \pm 0.18 b$ & 90.0 \\
\hline 2.0 & $1.00 \pm 0.00 \mathrm{a}$ & 100.0 & $0.86 \pm 0.34 b$ & 86.6 \\
\hline 4.0 & $0.96 \pm 0.18 \mathrm{a}$ & 96.6 & $1.00 \pm 0.00 \mathrm{a}$ & 100.0 \\
\hline 6.0 & $1.00 \pm 0.00 \mathrm{a}$ & 100.0 & $1.00 \pm 0,00 \mathrm{a}$ & 100.0 \\
\hline 8.0 & $1.00 \pm 0.00 \mathrm{a}$ & 100.0 & $1.00 \pm 0.00 \mathrm{a}$ & 100.0 \\
\hline 10.0 & $1.00 \pm 0.00 \mathrm{a}$ & 100.0 & $1.00 \pm 0.00 \mathrm{a}$ & 100.0 \\
\hline
\end{tabular}

Note. ${ }^{\mathrm{a}}$ Number of repetitions per treatment (1 first instar caterpillar per repetition). ${ }^{\mathrm{b}}$ Mean \pm standard deviation followed by the same letter in the column do not differ by the Scott-Knott test $(\mathrm{P}<0.05)$.

The insecticidal effect caused by the ingestion of aqueous neem extract was evident even at the lowest concentrations, with mortality rates above $60 \%$, probably due its antifeedancy properties, as observed by Jesus, Paiva, Gonçalves, Marques, and Boiça Junior (2011) in P. xylostella. This mode of action is attributed to the presence of azadiractin (Torres et al., 2006; Mondédji et al., 2015). Although no chromatographic methods were carried out to examine the composition of this extract in this study, the high mortality rate of caterpillars is likely due to azadiractin, as this is the most effective bioactive compound of Azadirachta indica (Schmutterer, 1990) and is easily extracted in an aqueous solution (Borges, Bucek, Camargos, \& Finzer, 2019).

According to Boursier, Bosco, Coulibaly, and Negre (2011), the empirical technique of aqueous extraction of neem seeds provides approximately $200 \mathrm{mg} \mathrm{L}^{-1}$ of azadiractin $\mathrm{A}$, which is much higher than the commercial product Neemarin with $0.15 \%$ azadiractin (Ahmad \& Ansari, 2012). According to these authors, neemarim is indicated for the management of $P$. xylostella because of its promising pest control results and low impact on natural enemies.

Although azadiractin is the main component of aqueous neem extracts, other compounds with insecticidal action might be present, such as nimbin and salanin, enhancing the effects of neem (Kudom, Mensah, \& Botchey, 2011). According to these authors, these compounds in neem inhibit ecdysone 20-monooxygenase, an important enzyme for molting.

Similar to neem extract, aqueous tobacco extract caused the mortality of caterpillars, even at the lowest concentrations $(0.5,1.0$, and $2.0 \%$ ), but $100 \%$ mortality was achieved only starting at the concentration of $4.0 \%$ (Table 1). Previous observations have already indicated the efficacy of aqueous tobacco extract on neonate caterpillars (first instar) of $P$. xylostella, but at higher concentrations than those reported in this study (Boiça Junior, Medeiros, Torres, \& Chagas Filho, 2005; Dequech, Egewarth, Sausen, Sturza, \& Ribeiro, 2009; Cerda et al., 2017).

It should be pointed out that the mode of action via ingestion of tobacco extract is not commonly reported. Nicotine is its active ingredient and acts on contact when absorbed by the integument of insects (Prado Ribeiro et al., 2016). It affects the nervous system, as it is analogous to acetylcholine, quickly resulting in insect death (Jacomini, Temponi, Alves, Silva, \& Jorge, 2016).

The effects of the aqueous extracts of neem and tobacco on P. xylostella caterpillars by ingestion are of special interest since neonate caterpillars of this species have a mining habit and movement between leaves is minimal. This decreases the efficacy of contact insecticides and reinforces the importance of using products that are ingested. Compounds with this mode of action enter the insect when feeding, which may affect its ability to digest and use food, the biosynthesis of hormones, or the formation of the chitin layer of insect cuticle (Begum, Sharma, \& Pandey, 2010).

\subsection{Effects of Aqueous Extract on P. xylostella Eggs}

Aqueous extracts affected the embryonic development of $P$. xylostella with a rate of non-viable eggs of up to $96.33 \%$ when treated with tobacco $(4.0 \%)$ and $84.66 \%$ with neem $(2.0 \%)$ (Table 2$)$. It should be pointed out that 
tobacco extract was more efficient than aqueous neem extract in the mortality of P. xylostella embryos (Table 2). This might be due to the higher concentration used of tobacco extract compared to that of neem.

Table 2. Average and percentage of non-viable eggs of Plutella xylostella treated with aqueous extracts of neem and tobacco $\left(25 \pm 3{ }^{\circ} \mathrm{C}, 60 \pm 10 \%\right.$, RH, Photophase $\left.12 \mathrm{~h}\right)$

\begin{tabular}{lll}
\hline Treatment & $(\mathrm{X} \pm \mathrm{SD})^{\mathrm{b}}$ & $\%$ \\
\hline Tobacco (4.0\%) & $28.9 \pm 4.33 \mathrm{a}$ & 96.33 \\
Neem $(2.0 \%)$ & $25.4 \pm 2.09 \mathrm{~b}$ & 84.66 \\
Control (distilled water) & $5.60 \pm 3.10 \mathrm{c}$ & 18.66 \\
\hline
\end{tabular}

Note. ${ }^{a}$ Number of repetitions per treatment (30 eggs per repetition). ${ }^{b}$ Mean \pm standard deviation followed by the same letter in the column do not differ by the Scott-Knott test $(\mathrm{P}<0.05)$.

The ovicidal properties of neem extract on P. xylostella has been previously reported (Torres et al., 2006; Hassan, Zada, \& Ahmad, 2018); however, this mode of action has not yet been reported for aqueous tobacco extract. This effect has been observed for the great southern white Ascia monuste orseis L. (Lepidoptera: Pieridae), completely inhibiting the eclosion of caterpillars due to the morphophysiological characteristics of the egg, such as thin chorion and unprotected micropyle, which allowed the entry of water-soluble compounds (Prado Ribeiro et al., 2016).

\subsection{Effects of Aqueous Extract on P. xylostella Oviposition}

Aqueous extracts of neem and tobacco exhibited ovideterrent activity against adults of $P$. xylostella $(\mathrm{PR}>0)$. Collard plants treated with aqueous neem extract showed a higher percentage of repellency $(42.33 \%)$ than those that were sprayed with aqueous tobacco extract (36.42\%) and both demonstrated greater repellency.

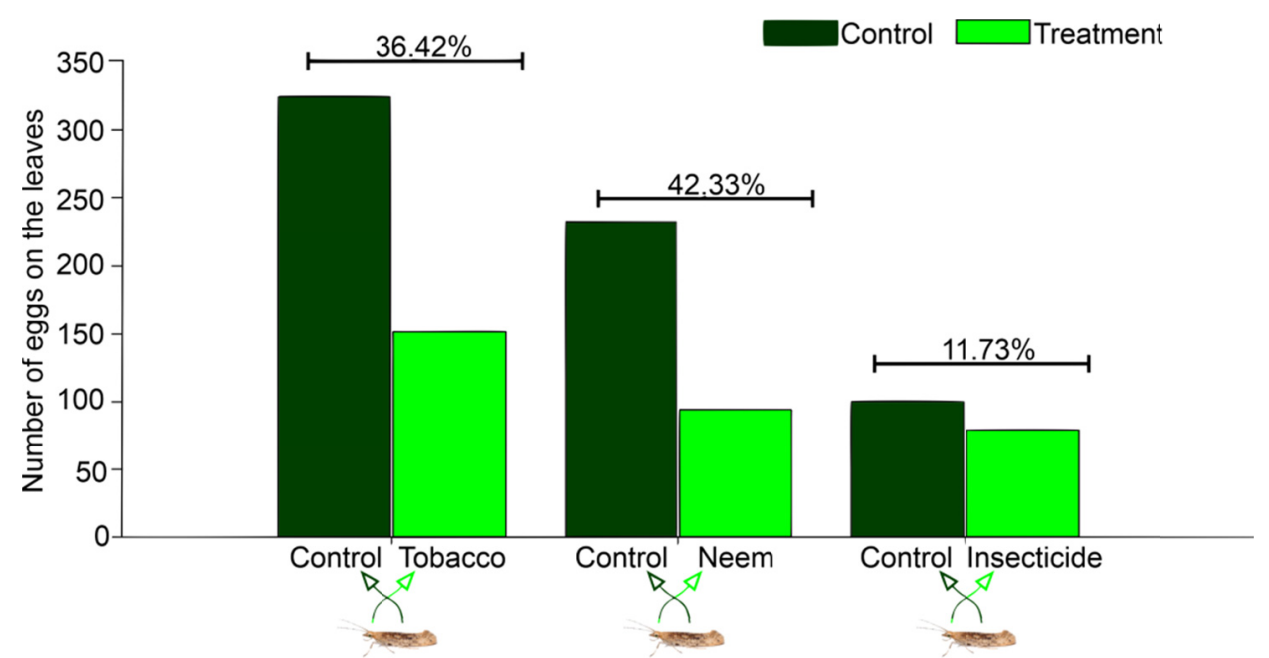

Figure 1. Percentage of repellency of oviposition, when adult females of Plutella xylostella were submitted to different treatments with a chance of choice, in the greenhouse. Tangará da Serra, MT, 2016

These results indicate that, even at low concentrations, the extracts altered the oviposition behavior of $P$. xylostella, as described by Torres et al. (2006) and Medeiros et al. (2005) when using neem extract and by Dequech et al. (2009) with tobacco extract. Regarding the ovideterrent activity of neem, Elanchezhyan and Vinothkumar (2015) reported that it might be due to its strong odor.

This property was also observed with aqueous extracts from the Amazonian plants Deguelia utilis (Papilionoideae), Xanthosoma purpuratum (Araceae), Clibadium sp. (Asteraceae), Witheringia solanacea (Solanaceae), and Dieffenbachia costata (Araceae) on the oviposition of P. xylostella, with emphasis on the latter species which had a strong negative effect (Cerda et al., 2019).

Couto et al. (2019) also reported a decrease in oviposition rate of $P$. xylostella exposed to aqueous extracts from the Cerrado species Schinus terebinthifolius (Anacardiaceae), Annona coriacea, A. crassiflora (Annonaceae) and 
Serjania marginata (Sapindaceae). According to these same authors, oviposition repellency occurred due to secondary metabolites present in the extracts of these plants.

The selection of extracts that exhibit an ovideterrent action against $P$. xylostella is an important tool, since in the field, a decrease in oviposition rate directly influences the number of caterpillars, therefore lowering leaf consumption and consequently reducing damage to collard crops.

The use of plant extracts in pest control is a promising alternative for family farming, as it is easy to access and has laboratory-proven efficiency due to the non-viability of eggs, caterpillar mortality and oviposition repellency. However, field studies are still needed to confirm this efficiency.

\section{Acknowledgements}

The authors thank the Coordination for the Improvement of Higher Education Personnel-CAPES for the fellowship granted and to Dr. Celice Alexandre Silva for identifying and depositing the botanical specimen.

\section{References}

Ahmad, N., \& Ansari, M. S. (2012). Effect of neemarin on life table indices of Plutella xylostella (L.). Crop Protection, 38, 7-14. https://doi.org/10.1016/j.cropro.2012.03.006

Al-Anany, M. S., El-Sheshtawy, A. A., Ghanem, Kh. M., \& El-Arnaouty, A. (2017). Insecticidal activity of certain organic extracts against citrus mealybug adult, Planococcus citri (Risso) and its natural enemy Chrysoperla carnea (Steph.) under organic farming systems. Journal of Chemical Environmental and Biological Science, 12, 273-296.

Amoabeng, B. W., Gurr, G. M., Gitau, C. W., \& Stevenson, P. C. (2014). Cost: Benefit analysis of botanical insecticide use in cabbage: Implications for smallholder farmers in developing countries. Crop Protection, 57, 71-76. https://doi.org/10.1016/j.cropro.2013.11.019

Begum, N., Sharma, B., \& Pandey, R. S. (2010). Evaluation of insecticidal efficacy of Calotropis procera and Annona squamosa ethanol extracts against Musca domestica. Journal of Biofertilizers \& Biopesticides, 1 , 101-105. https://doi.org/10.4172/2155-6202.1000101

Boiça Junior, A. L., Medeiros, C. A. M., Torres, A. L., \& Chagas Filho, N. R. (2005). Effect of plant aqueous extracts on the development of Plutella xylostella (L.) (Lepidoptera: Plutellidae), on collard greens. Arquivos do Instituto Biológico, 72, 45-50.

Bon, H. de., Huat, J., Parrot, L., Sinzogan, A., Martin, T., Malézieux, E., \& Vayssières, J. F. (2014). Pesticide risks from fruit and vegetable pest management by small farmers in sub-Saharan Africa. A review. Agronomy for Sustainable Development, 34, 723-736. https://doi.org/10.1007/s13593-014-0216-7

Borges, C. E. F., Bucek, E. U., Camargos, M. T. B., \& Finzer, J. R. D. (2019). Influence of water on ethanolic extraction yield of Azadirachta indica leaf. Journal of Analytical \& Pharmaceutical Research, 8, 71-72. https://doi.org/10.15406/japlr.2019.08.00315

Boursier, C. M., Bosco, D., Coulibaly, A., \& Negre, M. (2011). Are traditional neem extract preparations as efficient as a commercial formulation of azadirachtin A? Crop Protection, 30, 318-322. https://doi.org/ 10.1016/j.cropro.2010.11.022

Cerda, H., Carpio, C., Ledezma-Carrizalez, A. C., Sanchez, J., Ramos, L., Muñoz-Shuguli, C., ... Chiurato, M. (2019). Effects of aqueous extracts from amazon plants on Plutella xylostella (Lepidoptera: Plutellidae) and Brevicoryne brassicae (Homoptera: Aphididae) in Laboratory, semifield, and field trials. Journal of Insect Science, 19, 1-9. https://doi.org/10.1093/jisesa/iez068

Cerda, H., Ledezma-Carrizalez, A. C., Andino, M., Chiurato, M., \& Carpio, C. (2017). Insecticidal activity of twelve common amazon ecuadorian plants against Plutella xylostella (Lepidoptera: Plutellidae): Laboratory results. Mysore Journal of Agricultural Sciences, 51, 132-135.

Couto, I. F. S., Silva, S. V., Valente, F. I., Araújo, B. S., Souza, S. A., Mauad, M., Scalon, S. P. Q., \& Mussury, R. M. (2019). Botanical extracts of the brazilian savannah affect feeding and oviposition of Plutella xylostella (Linnaeus, 1758) (Lepidoptera: Plutellidae). Journal of Agricultural Science, 11, 322-333. https://doi.org/ 10.5539/jas.v11n5p322

De Bortoli, A. S. Polanczyk, R. A. Vacari, A. M., De Bortoli, C. P., \& Duarte, R. T. (2013). Plutella xylostella (Linnaeus, 1758) (Lepidoptera: Plutellidae): Tactics for Integrated Pest Management in Brassicaceae. In S. Soloneski \& M. Larramendy (Eds.), Weed and Pest Control-Conventional and New Challenges (pp. 31-51). Croatia: Janeza Trdine. https://doi.org/10.5772/50276 
Dequech, S. T. B., Egewarth, R., Sausen, C. D., Sturza, V. S., \& Ribeiro, L. P. (2009). Action of plants extracts on oviposition and on mortality of diamondback moth. Ciência Rural, 39, 551-554. https://oi.org/10.1590/ S0103-84782008005000078

Elanchezhyan, K., \& Vinothkuma, B. (2015). Neem: An Eco-Friendly Botanical Insecticide in Pest Management. Photon, 116, 207-217.

Faria, S. A. D. S. C., Arruda, V. A. S. D., Araújo, E. D. S., \& Penteado, M. D. V. C. (2017). Vitamin K: content in food consumed in São Paulo, Brazil. Brazilian Journal of Pharmaceutical Sciences, 53, 1-8. https://doi.org/ $10.1590 / \mathrm{s} 2175-97902017000215197$

Gahukar, R. T. (2014). Factors affecting content and bioefficacy of neem (Azadirachta indica A. Juss.) phytochemicals used in agricultural pest control: A review. Crop Protection, 62, 93-99. https://doi.org/ 10.1016/j.cropro.2014.04.014

Hassan, E., Zada, H., \& Ahmad, B. (2018). Effect of different neem extracts on Plutella xylostella (Lepidoptera; Plutellidae) under laboratory conditions. Journal of Agricultural \& Crop Science, 1, 1-5. https://doi.org/ 10.31872/2018/JACS-100101

Jacomini, D., Temponi, L. G., Alves, L. F. A., Silva, E. A. A., \& Jorge, T. C. M. (2016). Tobacco extract in the control of the mealworm beetle in aviaries. Pesquisa Agropecuária Brasileira, 51, 680-683. https://doi.org/ 10.1590/S0100-204X2016000500032

Jesus, E. G., Paiva, L. A., Gonçalves, V. C. Marques, M. A., \& Boiça Junior, A. I. (2011). Effect of insecticidal plants on the biology and behavior of Plutella xylostella (Lepidoptera: Plutellidae). Arquivos do Instituto Biológico, 78, 279-285. https://doi.org/10.1590/1808-1657v78p2792011

Jiang, T., Wu, S., Yang, T., Zhu, C., \& Gao, C. (2015). Monitoring field populations of Plutella xylostella (Lepidoptera: Plutellidae) for resistance to eight insecticides in China. Florida Entomologist, 98, 65-73. https://doi.org/10.1653/024.098.0112

Kianpour, R., Fathipour, Y., Karimzadeh, J., \& Hosseininaveh, V. (2014). Influence of different host plant cultivars on nutritional indices of Plutella xylostella (Lepidoptera: Plutellidae). Journal of Crop Protection, $3,43-49$.

Kudom, A. A., Mensah, B. A., \& Botchey, M. A. (2011). Aqueous neem extract versus neem powder on Culex quinquefasciatus: Implications for control in anthropogenic habitats. Journal of Insect Science, 11, 1-9. https://doi.org/10.1673/031.011.14201

Lengai, G. M. W., Muthomi, J. W., \& Mbega, E. R. (2020). Phytochemical activity and role of botanical pesticides in pest management for sustainable agricultural crop production. Scientific African, 7, 1-13. https://doi.org/10.1016/j.sciaf.2019.e00239

Medeiros, C. A. M., Boiça Junior, A. L., \& Torres, A. L. (2005). Effect of plants aqueous extracts on oviposition of the diamondback, in kale. Bragantia, 64, 227-232. https://doi.org/10.1590/S0006-87052005000200009

Melo, R. A. C., Vendrame, L. P. C., Madeira, N. R., Blind, A. D., \& Vilela, N. J. (2017). Caracterização e diagnóstico da cadeia produtiva de brássicas nas principais regiões produtoras brasileiras (Documentos 157). Brasília: EMBRAPA.

Mitidiero Junior, M. A., Barbosa, H. J. N., \& Sá, T. H. (2017). Who produces food for the brazilians? 10 years of the agricultural census 2006. Revista Pegada, 18, 07-77. https://doi.org/10.33026/peg.v18i3.5540

Mondédji, A. D., Nyamador, S. W., Amevoin, K., Ketoh, G. K., Phillippe, G., \& Glitho, I. (2015). Treatment and post-treatment effects of neem leaves extracts on Plutella xylostella (Lepidoptera: Plutellidae). African Journal of Agricultural Research, 10, 472-476. https://doi.org/10.5897/AJAR2014.9314

Obeng-Ofori, D. (1995). Plant oils as grain protectants against infestations of Cryptoles pusillus and Rhyzopertha dominica in stored grain. Entomologia Experimentalis et Aplplicata, 77, 133-139. https://doi.org/10.1111/ j.1570-7458.1995.tb01993.x

PARA (Programa de Análise de Resíduos de Agrotóxicos em Alimentos). (2013). Relatório de atividades de 2011 a 2012. Brasília: ANVISA.

Prado Ribeiro, L., Biermann, A. C. S., Dorneles, M. P., \& Vendramim, J. D. (2016). Ação de inseticidas botânicos sobre o curuquerê-da-couve. Agropecuária Catarinense, 29, 84-89. 
R Core Team (2014). R: A Language and Environment for Statistical Computing. R Foundation for Statistical Computing, Vienna. Retrieved from http://www.R-project.org

Raguraman, S., \& Kannan, M. (2014). Non-target effects of botanicals on beneficial arthropods with special reference to Azadirachta indica. In D. Singh (Eds.), Advances in plant biopesticides (pp. 173-205). New Delhi: Springer. https://doi.org/10.1007/978-81-322-2006-0_10

Salim, H. A. \& Abed, M. S. (2015). Effect of botanical extracts, biological and chemical control against Spilosoma oblique on cabbage (Brassica oleracea). Journal of Entomology and Zoology Studies, 3, 43-46.

Torres, A. L., Boiça Junior, A. L., Medeiros, C. A. M., \& Barros, R. (2006). Effect of aqueous extracts of Azadirachta indica (A. Juss), Melia azedarach (L.) and Aspidosperma pyrifolium (Mart.) on the development and oviposition of Plutella xylostella (L.) (Lepidoptera: Plutellidae). Bragantia, 65, $447-457$. https://doi.org/10.1590/S0006-87052006000300011

Trani, P. E., Tivelli, S. W., Blat, S. F., Prela-Pantano, A., Teixeira, E. P., Araújo, H. S., ... Novo, M. C. S. S. (2015). Couve de folha: do plantio à pós-colheita (Boletim Técnico 214). Campinas: IAC.

\section{Copyrights}

Copyright for this article is retained by the author(s), with first publication rights granted to the journal.

This is an open-access article distributed under the terms and conditions of the Creative Commons Attribution license (http://creativecommons.org/licenses/by/4.0/). 